\title{
Analysis of Income Tax Incentives during the Covid-19 Pandemic in Indonesia
}

\author{
Albert Lodewyk Sentosa Siahaan ${ }^{1 *}$ iD \\ ${ }^{1}$ Pelita Harapan University, Medan, Indonesia \\ *Corresponding author: albertlodewyksiahaan@gmail.com
}

\section{Abstract}

The Covid-19 pandemic since the beginning of 2020 has had a major impact on Indonesia's economic conditions. Due to the effects of the Covid-19 Pandemic, not a few companies have laid off or laid off their employees. In these circumstances, many people will no longer have income or have reduced income. Reduced income and the impact of the Covid-19 Pandemic on the economy greatly affected taxation, one of which was Income Tax (PPh). Income Tax (PPh) is a tax imposed on income received or earned by individual taxpayers or corporate taxpayers in one tax year. Therefore, the Indonesian government has implemented tax incentives for taxpayers affected by Covid-19. The government provides tax incentives with the aim of reducing the economic impact of the Covid-19 pandemic.

Keywords: Covid-19, Income Tax, Incentives, Tax

\section{History:}

Received: February $11^{\text {th }} 2021$

Accepted: February 20 ${ }^{\text {th }} 2021$

Published: February $26^{\text {th }} 2021$
Publisher: Universitas PGRI Madiun

Licensed: This work is licensed under

a Creative Commons Attribution 3.0 License

\section{INTRODUCTION}

The COVID-19 pandemic has a huge impact on the economy, social and politics of not only big countries but almost all countries in the world. It seems that there is not a single country that is not affected by the current COVID-19 pandemic ('Covid-19 And Implications For Micro, Small And Medium Enterprises', 2020). Pandemic Coronavirus Disease 2019 (“ Covid-19") was declared by the World Health Organization (WHO) as a global pandemic on March $11^{\text {th }}, 2020$. This determination was made due to consideration of the spread of Covid19 which has reached an alarming level. In response to the Covid-19 Pandemic, Indonesia imposed Large-Scale Social Restrictions (" PSBB ") with the aim of limiting people from gathering in large numbers to prevent the spread of Covid-19. The decline in the economic sector with sluggish economic activity had an impact on companies so that these companies were forced to close their companies and even terminate their employment relationships. At first, Covid-19 only spread to three Indonesians. However, after a period of time, there were many people with an increase of about a thousand each day. Of course this is a concern and a danger to at least three aspects of life that have the most impact, namely health, economy and education (Arrizal 2020).

The decline in turnover Perpetrators of SMEs and cooperatives due to covid-19 significantly since its appearance at the end of 2019. The tourism industry is one of the industries affected by the spread of this virus. The sluggishness of the tourism sector has a domino effect on the MSME sector. Based on data processed by P2E LIPI, the impact of the decline in tourism on MSMEs engaged in micro food and beverage business reached $27 \%$. Meanwhile, the impact on small food and beverage businesses was $1.77 \%$, and medium enterprises was $0.07 \%$. The effect of the Covid-19 virus on handicraft units made of wood 
and rattan, micro businesses will be at $17.03 \%$. For small businesses in the wood and rattan handicraft sector $1.77 \%$ and medium enterprises $0.01 \%$. Meanwhile, household consumption will also be corrected between $0.5 \%$ to $0.8 \%$. All actions taken by the government to reduce the impact of the COVID-19 pandemic, what should be done, is that the central government must be ready to carry out a national command, and guarantee security and safety for all Indonesian citizens (Soares, 2013).

Indonesia's economic growth in 2020 was originally estimated at $5.3 \%$. However, this figure was corrected as a result of the Corona pandemic, and some people predicted growth below $2 \%$. Given the uncertainty and different predictions, as well as fluctuations in the USD exchange rate (a drastic increase to IDR 16,000 per USD in early April 2020), the authors choose to ignore these two factors, namely the economic growth of January-April 2020 and the USD exchange rate at times of crisis. So that the GDP figures used in this paper are the 2019 reference. A major task rests on the shoulders of the Indonesian Government regarding the current COVID-19 pandemic: first, maintaining the safety and health of the Indonesian people as the main focus and second, maintaining the rate of economic growth ('Covid-19 And Implications For Micro, Small And Medium Enterprises ', 2020). A major task rests on the shoulders of the Government of Indonesia in relation to the current 'Covid-19 pandemic: first, maintaining the safety and health of the Indonesian people as the main focus and second, maintaining the pace of economic growth ('Covid-19 And Implications For Micro, Small And Medium Enterprises', 2020). Indonesia itself has made restriction policies for travel to and from countries that are in the red zone of transmission during the Covid-19 pandemic with the aim of breaking the chain of transmission of Covid-19, this step follows policies that have been implemented by several countries (Nasution, Erlina and Muda, 2020).

One of the pillars of national economic resilience is tax revenue. One of the taxes imposed by Indonesia is income tax (" $\mathrm{PPh}$ "). Based on Article 1 and the explanation of Article 1 of Law Number 7 of 1983 concerning Income Tax and all its amendments in Law Number 36 of 2008, that $\mathrm{PPh}$ is a tax imposed on individuals or individuals and entities with respect to income received or earned in one tax year. The Tax Subject is subject to tax if he receives or earns income, and hereinafter the Tax Subject is referred to as the Taxpayer. The impact of the Covid-19 pandemic has resulted in low investor sentiment towards the market which in turn has led to a negative trend. However, after the phase 1 agreement was reached in January 2020, the trade war between the United States and China began to appear to decline (Amri, 2020). Indonesia itself has made restriction policies for travel to and from countries that are in the red zone of transmission during the Covid-19 pandemic with the aim of breaking the chain of transmission of Covid-19, this step follows policies that have already been implemented by several countries ( 'Covid-19 And Implications For Micro, Small, And Medium Enterprises', 2020) The Ministry of Cooperatives and MSMEs said that cooperatives engaged in services and production were also most affected by the Covid-19 pandemic (Hanoatubun, 2020). The second impact of Covid-19, namely the continuous uncertainty that makes investment weaker and has an impact on the sustainability of businesses that are threatened to stop. The third impact of Covid-19 was an economic downturn that occurred around the world which caused commodity prices to fall and Indonesia's exports to several countries also stopped (Indaryani, Budiman and Mulyani, 2020).

The existence of the Covid-19 Pandemic affects the productivity of the community from workers to business actors so that it affects the Indonesian economy, therefore it is necessary to have regulations related to the provision of tax incentives that provide relief to the public, especially taxpayers, so that they can overcome the impact of the Covid-19 Pandemic on the economy. Tax incentives are expected to facilitate and help taxpayers' cash flow in the midst of difficulties. Given that the impact of the Covid-19 Pandemic has an impact on decreasing turnover for business actors and has an impact on labor because of 
decreased income. Therefore, the government issued Regulation of the Minister of Finance of the Republic of Indonesia number 86 / PMK.03 / 2020 concerning Tax Incentives for Taxpayers Affected by the Corona Virus Disease 2019 Pandemic which was further amended by Regulation of the Minister of Finance of the Republic of Indonesia Number 110 / PMK.03 / 2020 (hereinafter referred to as Permenkeu 110/2020) which can ease the burden on taxpayers during the Covid-19 Pandemic.

\section{MATERIALS AND METHODS}

This article uses a normative method with qualitative analysis.

\section{RESULTS AND DISCUSSION}

Based on Article 1 of the Income Tax Law, Income Tax is a tax imposed on individuals or companies and entities with respect to income received or earned in one tax year. In addition, $\mathrm{PPh}$ is a tax imposed on individual tax subjects or corporate tax subjects on the income they receive or earn during a tax year (Adrian Sutedi, 2011). Based on this understanding, that if a person or entity earns income, that person or entity will be taxed on their income in one tax year. Based on Law Number 28 of 2007 concerning General Provisions and Tax Procedures (hereinafter referred to as KUP Law), taxpayers are individuals or entities that are obliged to make tax payments, including tax collection or certain tax deductions. Income tax subjects who are subject to income tax are referred to as taxpayers.

Furthermore, based on Article 23A of the 1945 Constitution of the Republic of Indonesia, that taxes and other levies of a coercive nature with the aim of using these funds for state purposes are regulated by law. Whereas based on this matter, tax imposition must be regulated in a law as a legal basis so that it is not collected without legal basis. Whereas the law that is meant for the imposition of taxes for Income Taxpayers is the Taxation Law and the KUP Law. Based on Article 3 of the KUP Law, the imposition of PPh uses a selfassessment system, where taxpayers are asked to register at the Tax Office to obtain a Taxpayer Identification Number (NPWP). The second impact of Covid-19, namely the continuous uncertainty that makes investment weaker and has an impact on the sustainability of businesses that are threatened with stopping. The third impact of Covid-19 was an economic downturn that occurred around the world which caused commodity prices to fall and Indonesia's exports to several countries also stopped.

Furthermore, that in the sense of Income Tax as referred to in Article 1 of the Income Tax Law, Income Tax is imposed on tax subjects who earn income. Based on Article 4 paragraph (1) of the Income Tax Law, the income that becomes the object of PPh is the entire increase in economic capacity obtained or received by the taxpayer for consumption or for adding to his wealth in any name or form. Based on the definition of income, it can be concluded that the income of the $\mathrm{PPh}$ taxpayer does not pay attention to the source of income, but on the increase in the economic capacity of the PPh taxpayer. The increase in the economic capacity of the taxpayer is subject to PPh by the state as a form of sharing the costs of the government's needs for state development for the welfare of its people.

\section{Tax Incentives for Taxpayers Affected by Covid-19}

Tax incentives are special tax provisions which can be in the form of exemptions from tax objects, special tax rate treatment, or deferral of tax obligations (Kartiko and Pajak, 2020). One of the tax incentive provisions implemented by the Government during the Covid-19 Pandemic was the Covid-19 Tax Incentive which was stipulated in the Regulation of the Minister of Finance of the Republic of Indonesia Number 110 / PMK.03 / 2020 concerning Tax Incentives for Taxpayers Affected by the Corona Virus Disease 2019 Pandemic ( hereinafter referred to as PMK 110/2020). The provisions of PMK 110/2020 
were previously regulated in PMK 44 / PMK.03 / 2020 concerning Tax Incentives for Taxpayers Affected by the Corona Virus Disease 2019 Pandemic. The incentives given in PMK 110/2020 are:

a. Government Borne Income Tax Article 21 (DTP)

Income Tax Article 21 is a tax on income in the form of salaries, wages, honoraria, benefits and other payments in any name and in any form in connection with work or position, services and activities carried out by individual tax subjects, for example, permanent employees, labor freelance, or employee of certain activities.

Previously, in PMK 44/2020 the PPh Article 21 DTP incentive was given during the April 2020 tax period to the September 2020 tax period, which was then amended by PMK 110/2020, with the Article 21 DTP PPh Incentive given during the April 2020 tax period to December 2020 In PMK 110/2020, taxpayers who wish to receive PPh Article 21 incentives to be borne by the government must carry out administrative requirements as stated in PMK $110 / 2020$, for example, that taxpayers of Article $21 \mathrm{PPh}$ are required to apply for a Income Tax Free Certificate. Article 21 and so on.

b. Income Tax Article 22 related to Import

The definition of PPh Article 22 is Income Tax imposed on certain business entities with business activities namely import, export and / or re-import trade. Article 22 Income Tax related to imports is exempted from April 2020 to December 2020. That the Taxpayers of Article 22 PPh will get PPh exemption by the Government based on PMK 110/2020. Taxpayers with $\mathrm{PPh}$ Article 22 related to Import must meet requirements that are administrative in nature, namely to apply for tax free of Income Tax Article 22.

c. $50 \%$ reduction of Article 25 Income Tax installments

The definition of Income Tax Article 25 is a tax that is paid in installments every month in a tax year. The subjects of Income Tax Article 25 are individual or corporate taxpayers who carry out business activities as retailers or service delivery. An example of an Article 25 Income Tax Subject is a company that sells its food production goods to supermarkets or shops. Those entitled to receive a reduction in the amount of PPH Article 25 installments by $50 \%$ are Taxpayers who have a certain Business Field Classification code, KITE Companies, or companies with a Bonded Zone Operation permit. A 50\% reduction in Article 25 PPH Angusran will take effect for the tax period July 2020 to December 2020.

The role of income tax (PPh) in development and national economic resilience in the face of Covid-19

Tax collection is not only an obligation but also a right, given that tax revenue will be used for national development as the people's participation. In the fiscal year, the tax contribution as a state revenue dominates in the State Revenue and Expenditure Budget (" APBN "). Whereas in the 2019 State Budget, it was recorded that tax revenues were IDR 603.34 trillion or $38.57 \%$ of the APBN. Whereas it can be concluded, Tax (one of which is $\mathrm{PPh}$ ) is a form of tax subject obligation imposed by the State to support / assist the state budget, so that the state can carry out its functions and roles, and taxes become an important source of state revenue for governance and implementation of national development.

Given that the Covid-19 Pandemic greatly affected the economic sector, thus affecting the resilience of the national economy. In an effort to maintain national economic resilience and stability, the government must be careful in adjusting tax policy changes, one of which is the provision of tax incentives to keep the economic climate in mind during the Covid-19 pandemic.

Tax incentives are tax benefits used by the government for individuals or entities and even foreign investors to invest in Indonesia (Sitohang and Sinabutar, 2020). The tax incentives in PMK 110/2020 which are stipulated by the Minister of Finance are expected to facilitate and help taxpayers' cash flow in the midst of the Covid-19 Pandemic. However, 
considering that tax is the largest revenue in the APBN, the Government also needs to carefully examine the application of tax incentives, because with this tax incentive it will significantly reduce tax revenue, for example in 2019, $\mathrm{PPh}$ Article 21 on employee income, the realization of revenue is Rp. 148.63 Trillion. If tax incentives are given on PPh Article 21 , the state can lose quite a lot of state revenue. But on the other hand, PPh incentives are also expected to smoothen the cash flow of the community so that it will increase people's purchasing power to consume goods. In addition, during the Covid-19 Pandemic, the Government was in desperate need of funds, for example, Health Management required Rp. 75 Trillion and Social Safety Networks needed Rp. 110 Trillion, and especially for Tax Incentives and Government People's Business Credit, it needed Rp. 70 Trillion. One of the funding needs of the Government is the application of Tax Incentives, one of which is the $\mathrm{PPh}$ Tax which is contrary to the objectives of the Tax, which is to provide financial input to the Government to carry out development even to cope with the economy during the Covid19 Pandemic.

\section{Juridical review of Income Taxpayers who are required to pay Income Tax for handling Covid-19}

Income tax is classified as state tax or central tax. Income tax revenue is also classified as direct tax, which means tax that is borne by the taxpayer concerned and cannot be delegated to other people. Income Tax is a tax on income earned or received by individual taxpayers or corporate taxpayers on income earned during one tax year. The legal basis for the imposition of PPh is written in Article 4 paragraph (1) of the Income Tax Law , namely: " the object of tax is income, namely any additional economic capability received or obtained by the taxpayer, whether originating from Indonesia or from outside Indonesia, which can used for consumption or to increase the wealth of the taxpayer concerned by name and in whatever form, ...". That the imposition of tax on tax objects also has exceptions, meaning that not all income from taxpayers is subject to income tax. In addition, there is also the possibility of giving tax incentives provided by the Government. One of them is the establishment of Tax Incentives in the Minister of Finance Regulation 110/2020 to overcome economic problems during the Covid-19 Pandemic. Based on Presidential Decree No.12 of 2020 concerning Determination of Non-Natural Disaster for the Spread of Corona Virus Disease 2019 (Covid-19), the Covid-19 Pandemic has been declared a national non-natural disaster, so based on this it becomes a consideration in determining Tax Incentives for Taxpayers in the form of reduction taxable income (PKP) in the calculation of $\mathrm{PPh}$. However, to get an income tax incentive, the taxpayer must meet certain requirements in the Minister of Finance Regulation 86/2020 and the amendments to the Regulation of the Minister of Finance 110/2020.

This can be seen from the Government's steps that do not exempt all types of income tax, so that there is still tax revenue from income tax into the APBN. In addition, income tax incentives as stipulated in the Regulation of the Minister of Finance 110/2020 are a step to encourage the taxpayers to continue running their business activities and to earn income as referred to in the Tax Law accompanied by tax payment obligations assisted by an incentives tax program

\section{CONCLUSION}

Whereas every Government policy regulated in a taxation provision will affect the behavior of the Taxpayer. Taxpayers can comply or not comply with taxes. Whereas in accordance with the description above, the Government has taken steps that do not exempt all types of income tax, so that there will be tax revenue from income tax in the State Expenditure Budget. The policy benefit for taxpayers is a reduction in rates to exemption from taxes imposed in connection with income obtained by taxpayers (Padyanoor, 2020) . In 
addition, the Income Tax incentive as stated in the Regulation of the Minister of Finance $110 / 2020$ is a step to encourage the taxpayers to continue running their business activities and to earn income as referred to in the Tax Law accompanied by tax payment obligations assisted by an incentives tax program. The $\mathrm{PPh}$ incentive program as referred to by the Regulation of the Minister of Finance 110/2020 is a program to encourage people to continue to pay income tax at a rate that is not high and is a form of government assistance to alleviate the burden on their people. In addition, the Income Tax incentive program also maintains the quality of the entry of state revenues into the APBN in terms of taxation, especially income tax. The PPh tax incentive is also expected to be a stimulant for the community to continue to carry out business / economic activities in order to maintain cash flow in the community, this can be seen with the Article 25 tax exemption related to imports, on the other hand Article 21 tax incentive is expected to maintain people's purchasing power by does not burden the income of Taxpayers affected by Covid-19. On the other hand, the provision of tax incentives also burdens the state to spend Rp. 70 trillion in funds, while the state during the Covid-19 Pandemic was in need of financial input to run or tackle Covid-19. The key to restoring national economic conditions is survival at the individual and business entity level (Hadiwardoyo, 2020)

The suggestion that can be given by the author through this research is for the Government to be careful in implementing the incentive tax program so as not to significantly erode tax revenue in the process of dealing with the Covid-19 Pandemic. In addition, the Government may also establish policies other than taxation policies to keep receiving funds, such as by establishing a Pandemic Bond as one of the Government Securities (SBN). The government in this case is the tax authorities must always look carefully whether the taxpayer is really affected or not during the Covid 19 pandemic. Not all business sectors have been affected by the Covid 19 epidemic, such as the digital industry, games and e-commerce sectors, which are believed to have experienced an increase in dividends due to the stipulation of the PSBB in almost all of Indonesia

\section{ACKNOWLEDGMENTS}

I say thank to God, my family, Universitas Pelita Harapan Medan, and all friends who support me to finish this research.

\section{REFERENCES}

Arrizal, Nizam Zakka. 2020. “The Enforceability Force Majeure's Clause in Performance of Business Contracts During Pandemic Covid-19 in Indonesia." 499(Icolgas):409-17.

Amri, A. (2020) 'Dampak Covid-19 Terhadap UMKM di Indonesia', Jurnal Brand. 'COVID-19 DAN IMPLIKASI BAGI USAHA MIKRO, KECIL, DAN MENENGAH' (2020) Jurnal Ilmiah Hubungan Internasional. doi: 10.26593/jihi.v0i0.3870.59-64.

Hadiwardoyo, W. (2020) 'Kerugian Ekonomi Nasional Akibat Pandemi Covid-19', Baskara Journal of Business and Enterpreneurship.

Hanoatubun, S. (2020) 'Dampak COVID-19 Terhadap Perekonomian Indonesia', Journal of Education, Psychology and Counseling .

Indaryani, M., Budiman, N. A. and Mulyani, S. (2020) 'Dampak Covid-19 dan Pemanfaatan Insentif Pajak terhadap Keberlangsungan Usaha pada UMKM Tenun Troso Jepara', Jurnal Manajemen dan Keuangan, 9(3), pp. 276-285.

Kartiko, N. D. and Pajak, D. J. (2020) 'Insentif pajak dalam merespons dampak pandemi covid-19 pada sektor pariwisata', Jurnal Pajak Dan Keuangan Negara. 
Nasution, D. A. D., Erlina, E. and Muda, I. (2020) 'Dampak Pandemi COVID-19 terhadap Perekonomian Indonesia’, Jurnal Benefita. doi: 10.22216/jbe.v5i2.5313.

Padyanoor, A. (2020) 'Kebijakan Pajak Indonesia Menanggapi Krisis COVID-19: Manfaat bagi Wajib Pajak', E-Jurnal Akuntansi, 30(9), p. 2216. doi: 10.24843/eja.2020.v30.i09.p04.

Sitohang, A. and Sinabutar, R. (2020) 'Analisis Kebijakan Isentif Pajak Di Tengah Wabah Covid-19 Di Indonesia Alda Sitohang dan Romulo Sinabutar', Jurnal Ekonomi, 13, pp. $14-25$.

Soares, A. P. (2013) 'LANGKAH PENCEGAHAN VIRUS CORONA', Journal of Chemical Information and Modeling, 53(9), pp. 1689-1699.

Dampak Covid-19 Terhadap UMKM di Indonesia', Jurnal Brand. 'Covid-19 Dan Implikasi Bagi Usaha Mikro, Kecil, Dan Menengah' (2020) Jurnal Ilmiah Hubungan Internasional. doi: 10.26593/jihi.v0i0.3870.59-64

\section{Laws}

Law Number 36 Year 2008 on Income Tax $(\mathrm{PPh})$

\section{Internet}

Kebijakan perpanjangan insentif dituangkan dalam Peraturan Presiden No. 72 Tahun 2020 yang merevisi Perpres No. 54 Tahun 2020. https://news.ddtc.co.id/pemerintahperpanjanginsentif-pajak-hingga-desember-2020-21929?page_y=706.6666870117188. 